\title{
Community Participation (Analysis on Implementation of Policies on Village Development Guidelines Based on Permendagri No. 114 of 2014 in Simojayan Village, Ampelgading District, Malang Regency)
}

\author{
Sri Hartini Jatmikowati, Abdullah, Theodorus Pangalila
}

\begin{abstract}
The background in this study is that the Village Head has a role in the administration of governance, development and community issues with all of his authority and obligations. In its development, it was felt not enough because the community did not feel involved and did not know anything about the activities to be carried out. Development a sense of belonging from the community towards development projects, an approach is needed that encourages people to participate. This approach can streamline project implementation costs because of community participation. The purpose of this study was to describe and analyse the role of village heads in increasing community participation in Simojayan village, Ampelgading district, Malang district and supporting factors, inhibiting the role of village heads in increasing community participation. This study uses a qualitative approach with a specific level of exploration. The results of this study are the lack of maximum community participation in every stage of development, especially in the implementation phase of village development. The Village Head has given his participation by carrying out the tasks by his duties and carrying out the work plan of the village administration based on the needs of the community and the fulfilment of infrastructure facilities in the village. The driving and inhibiting factors are contradictions between policymakers and policy implementers, information capture, limited human resources and competence in carrying out activities. Researcher's suggestion is to build and develop active communication channels and make procedures through clear statements about requirements, objectives, eliminate the choice of multi-information, implement procedures carefully and mechanism for detailed reporting. Maximum language and communication need to be maximised to minimise communication gaps given the limited human resources and competencies.
\end{abstract}

Keywords: Policy, Role, Village Head, Participation, Society

\section{INTRODUCTION}

As an effort of groups or communities in order to achieve

Revised Manuscript Received on October 22, 2019

Sri Hartini Jatmikowati, Political and Social Science Faculty of Merdeka Malang University. srihartinijatmikowati@gmail.com

Abdullah, Political and Social Science Faculty of Merdeka Malang University

Theodorus Pangalila, Social Science Faculty of Manado State University the best conditions of the actual conditions, the activities that are systematically done are doing construction. Development needs to consider what belongs to Human Resources (HR) and Natural Resources (NR) in it. Also, the regulation in carrying out the development must be clear and appropriate.

The village, as a leading autonomous region unit in efforts to develop community welfare, needs to get more attention related to the authority in its management in order to improve the welfare of the community. Development is directed by developing a rural sustainability growth point that has economic, social and ecological embassies and encourages village and city relations. This development policy is carried out with strategies including organizing and implementing government as well as developing villages, fostering and empowering rural communities.

The village conducts the management of development, starting from the initial plan to the monitoring and evaluation. Besides that, besides being able to carry out development independently by the village, development can also involve cooperation between villages. This is done in connection with a development that cannot be carried out by the village itself either because of limited funds or the time of implementation.

Based on Law Number 6 of 2014 concerning Villages, the purpose of development in the village is to improve the quality of human life and improve the welfare of village communities and overcome poverty by fulfilling basic needs, building village facilities and infrastructure, developing local economic potential, and utilizing environment and natural resources in a sustainable manner. For this reason, 2016-2022 in the middle-village development planning is directed at improving village government officials and the BPD, strengthening the function and role in community institutions and strengthening the village community.

In some cases, the paradigm of participatory development in practice is not yet in line with the nature of the real participatory approach. This statement seems to be characterized by a region orientation in which the area base is less attention, short term and quantitative, 


\section{Community Participation (Analysis on Implementation of Policies on Village Development Guidelines Based on Permendagri No. 114 of 2014 in Simojayan Village, Ampelgading District, Malang Regency)}

focusing on providing resources/services, oriented to tools and techniques and non-functional point of view that is without considering the functional capacity of the community.

The most basic form of participation is information sharing, where development practitioners generally inform local communities about the plans for a particular development project. However, in its development, it was felt that it was not enough because the community did not feel involved and did not know anything about the activities to be carried out. Consultation with the community is only a formality needed to certify a development project. To develop a sense of belonging from the community towards development projects, an approach is needed to encourage the community to participate. This approach can streamline the cost of implementing the project because of community participation.

In the village, leadership is what the leader does to encourage, direct and regulate all elements of the organisation or group in order to achieve the expected goals. Village officials who have the authority, obligation and duty to take care of the household of their village and carry out work responsibilities given by the government and local government (Malang District Regulation No. 1 of 2016 concerning the village). That village leader has a role in the administration of issues of government, development, and society with all their authority and obligations.

The design of the RPJMD contains the mission and vision, guidelines in the development strategy, the agenda of activity consists of the field of implementation in developing the village, the implementation of village governance, fostering and empowering the village community. Defining the mission, vision and program of the regional head in arranging it based on the Regional RPJP by taking into account the provincial and national RPJM, the provision of guidelines on regional budget, regional development strategies, general strategies, and work unit programs, across the workforce in the region and programs in the region with various work agendas in the context of the rules and context of funds that have indicative traits that are the content of plans for regional mid-term development (RPJMD).

Based on these conditions, a study was conducted on "The Role of Village Heads in Improving Community Participation (Implementation Study Based on Permendagri Number 114 of 2014 concerning Village Development Guidelines in Simojayan Village, Ampelgading District, Malang Regency)".

\section{Literature REVIEW}

\section{A. Public Policy}

Public policy is based on inputs in the form of demands and supports from the wider community. From the input, it becomes the agenda in the discussion of public policy, as stated by Friedrich, in (1)Soenarko (2005:42), direction in action recommended to people, groups, or government in a domain where there are obstacles and opportunities in hopes of overcoming obstacles exist and fulfil the opportunity for the achievement of ideas and the realization of goals and intentions. Etymologically, public policy consists of two policy words and the public. According to Pasolong (2007) terms commonly used as public match are: a) Public interest, b) Public opinion, c) Public goods, d) Public law, e) Public sector, f) Public health, g) Public transportation, h) Public education, i) Public service broadcasts, j) Public accountability, k) Public toilets, 1) Public order, m) Public debt.

Policy is a set of goals and objectives of government programs (Kartasasmita in Widodo, 2011) explaining that policy is a way of understanding and knowing the meaning of what the government must do / not do on a problem, what influences it or why, and from the public policy what are the effects and impacts.

Public policy is the allocation of values, and goals to be realized by the government, and usually based on the value of the interests of the broader community in solving social problems that are occurring. Charles O. Jones in (4) explained about policies, namely guidelines for activities focused on achieving targets. Meanwhile, the approach in public policy is directed to facilitate the implementation. Public policy is made to solve a problem, so it is necessary to recognize the problems that occur so that public policy can be directed and achieved goals and objectives to be realized. Objectives often become the foundation in developing a strategy and tactics that allow for its implementation, tactics, and strategies in the form of steps needed to carry out public policy, through these steps so that implementation can be carried out consistently and directed.

Public policy also carries the risk of failure, as explained by Abdul Wahab (2002), namely: "Generally policies that have a risk of failure are due to factors including lousy execution, lousy policy or wisdom. This is indeed bad luck. For this reason, Hogwood and Gunn in (5), reminded that there are conditions in the implementation of policies, namely: 1) No serious obstacles/disturbances faced by the institution/agency in their external conditions; 2) Availability of sufficient resources and time in implementing the program; 3) Availability of a mix of resources needed; 4) Based on the quality relationship that is reliable in policy implementation; 5) At least the connection chain and the direct quality of the relationship; 6) The small relationship of interdependence; 7) There is agreement on the purpose and depth of understanding; 8) Proper order placement and task details; 9) Perfection of coordination and communication; and 10) Can sue and get perfection of compliance with parties that have authority.

\section{B. Implementation of Public Policy}

The implementation of public policy includes the efforts of policymakers in 
order to influence, by Lipsky called "street-level bureaucrats" to provide services/management to the behaviour of the target group or target group. The involvement of implementation in a body that has a function as an implementor is a simple policy, for example, policy to help the community to have a better life by building public infrastructure. In macro policy, for example, conducting various implementation efforts by including institutions including sub-district bureaucracies, districts, village governments to reduce rural poverty.

Public policy is a public policy process that is very important so that the policies set by the government have meaning in public life. The implementation of the policy is not only related to the method in describing political decisions into the bureaucratic process but more than that, related to issues of conflict, who gets and what decisions on a policy. For that, the implementation of public policy is seen as one of the parts or stages that are very strategic in all processes in public policy. Seven stages of the policy formulation process, namely:

- Assessing the problem, to find and understand the underlying meaning of the problem in a problem and then formulate it into a causal relationship.

- Determining goals is the stage of determining the goals to be achieved through public policy and formulated immediately.

- Alternative formulations. Alternatives are several solutions to problems that are solved, allowing it to be applied as an effort to achieve the stated objectives.

- Arranging the model, namely simplifying and the phenomenon of problems faced with a causal relationship and built with all kinds of models.

- Determining standards. In analysing the policy requires clear standards and consistency in the assessment of alternative policies offered. Standards used include regulatory standards, economics, community participation, technical, political, legal, and so on.

- Assessing alternatives. Assessing alternatives by using standards that aim to obtain the farthest description of the threshold of effectiveness and the feasibility of each alternative to achieve the goal.

- $\quad$ Formulate recommendations, compile based on the results of alternative policy studies that are predicted to be able to optimise the objectives achieved and with the least possible impact.

\section{Factors that Influence Policy Implementation}

Aspects of failure or success in implementing a policy according to Edwards in Widodo (2011) there are 4 (four), as follows: communication (communication), resources (resources), disposition (attitude), and bureaucratic structure (bureaucratic structure) The following is an explanation of the four factors:

Communicatio is the Latin language of communication, which means exchange or notification. Communication itself contains common meanings taken from the adjective communis, which has a general meaning (together). According to Widodo (2011), policy communication has the meaning of methods in conveying information about the policies of the public maker (who makes policies) on the policy of the implementor (implementing policies). Added, important information conveyed to policy actors so that the actors of the policy can understand the purpose of the target group, the content, and direction of the policy so that actors from the policy can prepare matters related to the implementation of the policy so that the process in implementing the policy can run effectively and harmoniously with the purpose of the policy itself. In policy implementation, communication consists of several main dimensions, namely transmission / transformation of clear information, clarity / information and consistent consistency / information. The transformation point of view wants the report not only to be delivered to policy implementers but also the target group and the linked parts. The clarity aspect wants the information to be clear and not difficult to understand. This is to avoid wrong views from policy implementers. The consistency aspect wants the report to be given consistently so that there is no confusion from the policy implementer, the group in the target or the related part.

Resource. Developments in achievements in the fields of culture, economy, education, politics, knowledge, law or development can undoubtedly lead to various obstacles and obstacles. With the presence of various obstacles and obstacles, we need strength and interrelationship in managing existing resources.

Disposition. Edwards III explains the disposition intended as an action, namely an implementor who plays a significant role in order to achieve successful implementation of the policy so that it fits with its objectives. As an example of honest, responsible and commitment that must be owned. The attitude or action will be able to guide the implementer consistently in the direction of the program that has been set. The responsibility and commitment of the executor is also a factor of enthusiasm in the implementation of duties, authority, functions, and responsibilities based on applicable rules.

In policy implementation, the actions of the implementor have influence. If the implementor has the right actions, it will also be good at implementing the policy. Conversely, if it is not supported by this action, the implementation does not go as expected.

Bureaucratic structure. According to Max Weber in Pace $\&$ Faules (2006), the bureaucratic structure in formal organizations has ten characteristics, namely:

- Includes ties determined between positions

- Tasks come from organizational plans or goals

- Within its authority, the position is given in order to carry out obligations

- Arrangement of positions and lines of authority by hierarchical systems

- $\quad$ The function of the office and actions are formally regulated because they are general but firm regulations and systems

- Institutional regulations apply to everyone; procedures 


\section{Community Participation (Analysis on Implementation of Policies on Village Development Guidelines Based on Permendagri No. 114 of 2014 in Simojayan Village, Ampelgading District, Malang Regency)}

are impersonal and formal

- $\quad$ Area procedure and attitude in order to implement a system of discipline as part of the institution

- The separation of institutional life from the personal lives of institutional members

- The election is based on technical for employees in working in their institutions

- Minority and work performance is the basis of promotion even though work in the bureaucracy is based on technical skills.

From the theory above, it is known that the routine tasks possessed by the bureaucratic structure are obtained by way of specificity, very formal rules and regulations, grouping tasks, centralized authority and decision making following the command line.

The organizational structure aspects include two things, namely the aspect of the mechanism where generally SOP (standard operation procedure) has been made as a guideline for all implementors in carrying out actions so that the implementation is not out of the policy goals and objectives. Then, in terms of the bureaucratic structure where fragmentation and large bureaucratic structures tend to make supervision weak and make bureaucratic procedures complicated and involved so that institutional activities are not flexible.

\section{Society Participation}

Reference to participation is the position of the subject that is part of or as part of a partner or partner, which means that part of laying an understanding of participation for the position of the perpetrator is only a role, taking part and having more tendency in the marginal position. Then, participation is expressed as participation or participation in the way the action is realized is not based on the original internal method of awareness that instils motivation in initiating or initiating an activity together. If the initiative is done by other groups, then the community participates. Partners themselves can be interpreted as:

- There are initiatives in working on actions by the subject;

- Having the same/equal position to do actions together with others (the others).

- Each party is ready and willing to bear the risk in conjunction with the actions taken together.

- Each party has a subjective or at least similar meaning to determine and carry out joint actions.

- The selection of actions together has gone through the process of "awareness space" so that the action is genuinely something that is desired to be done.

Cohen \& Uphoff (1980) define participation as community participation in the planning process or making decisions, implementing, enjoying the results and evaluating these results. Substantial participation consists of:

- Voice (voice) means that each citizen has space and rights to deliver votes in the process of governance and development. In this case, the government accommodates each vote that arises in the community and makes it the basis for making decisions.
- Access is an opportunity that the community has in accessing or influencing policymakers, including access to public services.

- $\quad$ Access, that is, every citizen has the opportunity to access or influence policy making, including access to public services.

- $\quad$ Supervision, each citizen/community element has the opportunity as well as matters in carrying out supervision/control over the running of government and management of policies and finance in the government.

Several strategies are needed in establishing community participation in village development plans, namely:

- Building commitment with the community together through the path of community involvement in village meetings and providing opportunities to the community in expressing ideas/ideas;

- $\quad$ The building of public trust through implementing direct approaches in the community. Become an example or primary executor in every activity.

Often success in development in society is influenced by the paradigm of the leader. The character of the leader will influence the role of the community. Therefore, a leader who cares about the community or its citizens is essential. Public figures are factors that lie in a leader. Community participation in development is linked to the activeness of government apparatus in the development process, meaning that the activity of government officials in the development process is an indicator of village community assessment.

\section{E. Village Midterm Development Plan}

Based on its authority, the village makes development planning refer to district/city development planning. In law number 6 of 2014 related to the village in article 79 paragraph 2 stated, the plan to build a village made in time consists of medium-term village development planning with a period of 6 years and a plan for annual village doubts called a plan of village government work that details originating in the village RPJM within a year. Development planning in the village in order to build the participation of the village community through village planning meetings.

The village government arranges plans for development activities in the village based on information from the district or city government based on the indicative ceiling of the village and the planning of government activities, provincial government and city/district government, as well as the evaluation of the previous year's development. This plan is the primary basis or reference in implementing development for village governments within a year, which is then included in the Village Budget in the relevant budgeting year.

In Law, it is explained that the village government has the authority to regulate and manage its government. However, in planning and arranging development, it is still obligatory to see a link between the plans in the city/district, village and between the village administration and the village

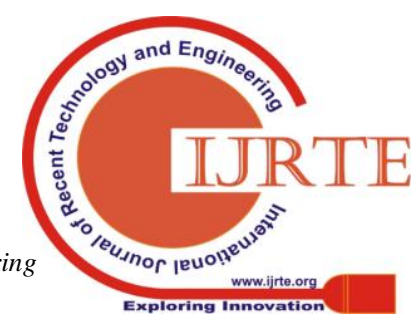


so that the achievements of the village can be a support for achieving the goals in developing the area.

The dimensions of the relationship between village institutions take into consideration the authority given by the local government in its relationship to the SDA as well as other resource management or together with finance and public services at the village level. The hope for the village government through regional autonomy can be to improve service quality, competency, economy that grows, equity, fairness in development and has the content to increase the strength and diversity of local resources.

Planning is an essential process in order to achieve the expected results in the implementation of development. The village development plan is the main discussion with the necessity of being done by the village government, as well as the form of vision and mission of the elected village head and set out in the Village RPMJ and a way of selecting activities for the future and in accordance with the choice of order considering the available resources.

- Must have, know and calculate the desired final goal.

- Objects and priorities in order to make them happen (reflected in various choices).

- $\quad$ The period of achieving the target.

- Problems faced.

- Resources or all capital to be used and allocation.

- Procedure.

- There are people, implementing agencies or organisations.

- The flow of monitoring, supervision of implementation and evaluation.

Widodo (2011), explains that in its implementation, the planning process must involve the village head as the subject of development. This system of community involvement consists of hearing advice carried out transparently in the majority of people who have a sense of care. The sharing was arranged in a way to facilitate interest groups, individuals and officials in contributing to the making of design and redesigning a policy aimed at gathering the information that made policy implementers produce better than policies. Tarigan (2009), explains that with participation, all plans will be more organised, the desires of citizens can be accommodated until the steps and objectives of the village government can be better and by the desired goals.

Article 1 paragraph 10 of Permendagri 114 of 2014 in general provisions explains that plans for development in the village are activities in activities where the village government is the organiser that participates BPD and community elements in a participatory manner in order to utilise and allocate village resources to achieve the objectives. So it appears, planning is the main activity in carrying out development and involving the community/community participation in order to fulfil what is needed by the community in the context of choosing decisions in a plan.

\section{Methodology/Materials}

The qualitative approach is the approach used in this study; the level of exploration has a descriptive nature. Qualitative research is a method in research that is used to conduct research in terms of natural objects (as opposed to experiments), researchers as principal instruments by collecting data through combination (triangulation), analysis data has inductive characteristics, and the results of qualitative research are emphasized in meaning rather than generalization (9). The collects data in this study is in-depth interviews, observations, documentation (study documentation), the use of this technique is to examine written statements, archives, documents related to research problems that have a relationship with this research, for example, regulations, implementation instructions, technical instructions and so forth.

The interactive model of Miles \& Huberman (1992), is an analysis of the data used in this study, namely: Collecting data, Data reduction, Data presentation, Verification (Conclusion Withdrawal).

\section{RESUltS AND FINDINGS}

\section{A. The role of the Village Head in increasing community participation in Simojayan Village, Ampelgading District, Malang Regency}

1) Communication

The Village Head is the whole part of village development that has more significant duties and responsibilities to the village community. As an integral part, the village head is inseparable from his organization, namely the village government. This role is the interaction with the organization of the village administration, meaning that the Village Head must be able to integrate between his personality and needs along with village government goals and structures. This becomes important in the context of ensuring the role of the Village Head can be carried out by the planning and fulfilment of the needs of the village community.

Communication is an essential part of the success of village development. Communication must be carried out thoroughly and transparently. The capacity of the Village Head in embracing and fostering his community is due to the socio-cultural situation in the village, which is still closely related to the community's village. The Village Head must be able to blend with the culture and society because it is part of the village community. Its proximity is also involved, not only in administrative terms but also in fostering social life in the village.

Communication factors influence the acceptance of policies from the target group so that the quality of communication can influence the achievement of the effectiveness of public policy implementation. Similarly, the dissemination of policy content through the communication process will affect the implementation of 


\section{Community Participation (Analysis on Implementation of Policies on Village Development Guidelines Based on Permendagri No. 114 of 2014 in Simojayan Village, Ampelgading District, Malang Regency)}

the policy. For this reason, the media used in the dissemination of policy content to the target group is significant.

The success of policy implementation requires that the implementor know what to do. What is the policy goals and objectives must be transmitted to the target group so that it will reduce the distortion of implementation? If the objectives and objectives of the policy are unclear or even not known at all by the target group in this case, also the village community, then there will likely be resistance from the target group.

\section{2) Resources}

The power of resources is essential in implementing a policy. Moreover, the requirement for an organisation to work is ownership of resources. These resources can be substantial human resources, namely the competence of the implementor and financial resources.

One solution to addressing the shortcomings in village apparatus resources is to provide opportunities for village officials to develop themselves, for example, through participation in training and seminars related to village implementation and activities.

The dimension of resource communication has a significant influence on the performance of village governance, both individually and together. The existence of low discipline or understanding of the duties and responsibilities that are not optimal from the village apparatus is a separate evaluation for the performance of the Simojayan village government apparatus.

\section{3) Infrastructure}

Physical facilities are an essential factor in policy implementation. The implementor may have sufficient, capable and competent staff, but without supporting facilities (facilities and infrastructure), the implementation of the policy will not succeed. Based on Law Number 6 concerning the Village and its Implementation Regulations, and so that the policy runs according to the mandate, every year the village government with the BPD establishes Village Regulations on Village Revenue and Expenditure (APB village) in a participatory and transparent manner which starts with village workshops, public consultations, and BPD Deliberation meetings for their determination. In this case, the facilities and infrastructure needed for both the village and the community will appear.

The RAPB Desa contains Revenue, Expenditures, and Financing whose management starts from January 1 to December 31. The village financial management policy for the 2017 fiscal year is a new financial management system for the village so that there are still many adjustments to be done thoroughly to the technical implementation.

\section{4) Village Development}

As explained earlier, that village development has the aim to improve the welfare of rural communities and the quality of their human life through meeting basic needs, building, developing potential and sustainable use of resources. The village prepares development planning by its authority based on city/district development planning. Where in Article 79 paragraph 2 of Law Number 6 of 2014, it is explained that village development planning is prepared in a timely manner including the Village Medium Term Development Plan for a period of 6 (six) years, and the Village Annual Development Plan, called the Village Government Work Plan, is elaboration of the Village Medium Term Development Plan for a period of 1 (one) year. Village Development Planning is carried out by involving village communities through Village Development Planning Consultations.

The assessment of the results in building the village in the previous year was carried out through an analysis of the similarity of activities planned at the Simojayan village RKP in 2016 as well as its implementation in the 2016 Village Budget and also an analysis of the 2016 proposed RKP Simojayan village proposed to the local government through the Musrenbang at the District level and the District by implementing district development activities that entered the village in 2016 .

In the framework of implementing priority programs and activities, villages have carried out several development activities. Village development in the field of social and cultural governance is one of them realized in the form of restoration of uninhabitable homes.

In order to achieve the maximum success of village development, activity is strongly influenced by the provisions of organisation, the work system carried out and its supporting elements, starting from the quality of the executor and the facilities needed.

So that in the implementation of village development organizing is needed which can move the community to participate in the development and carry out village administration that is increasingly rational, not based on emotional demands that are difficult to be held accountable for.

The Village Chief Simojayan explained that in the development of a region, infrastructure problems are the main thing in order to facilitate the economic activities of the community. If the infrastructure is available and maintained adequately, all community activities can be carried out efficiently and effectively.

\section{B. Driving and inhibiting factors both internally and externally}

1) Internal (Village)

Often found conditions where coordination and communication are not perfectly intertwined. Coordination and communication are two things that are easy to say but are the most difficult to do. The situation will be more difficult when the preconditions for the realization of communication no longer exist. Communication does play an essential role in coordination and implementation in general, but genuinely perfect communication is a painful condition to be realized. Coordination is certainly not just about the issue of

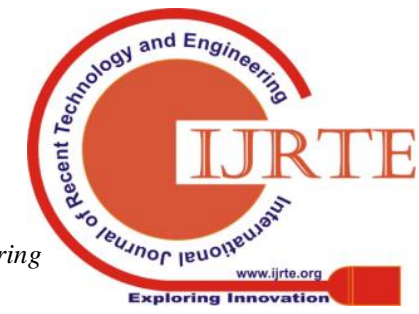


communicating information but also about more fundamental issues.

There are demands from the community for good governance, requiring the village government to carry out its activities accountably, transparently and encourage active participation or participation from the community. The village government must provide what is needed by the community, but internally, there are several obstacles, namely the limitations of competent human resources and the problem of limited funds. However, with the existence of village funds, the village government is required to be responsible for the absorption of funds and their physical form and usefulness for the community.

One of the drivers in village development is the role of the paternalistic village head resulting in a significant community role or participation. The presence and figure of the village head figure much support the success of village development. Its presence is needed in order to mobilise its community participation in developing villages in its territory, in the hope that there will be equitable development outcomes and foster ideas or constructive suggestions that develop within the village community.

\section{2) External (Community, Law)}

There are several common obstacles that commonly occur in communication transmission, namely: first, there is a conflict between the implementers of the policy and the orders issued by policymakers.

This kind of conflict will lead to distortions and direct obstacles in policy communication. Second, information is conveyed through layers of bureaucratic hierarchy. Communication distortion can occur because of the length of the information chain that can cause information bias. Third, the problem of information capture is also caused by the perceptions and inability of the implementers to understand the requirements of a policy.

According to Winarno (2005), factors that encourage information obscurity in the implementation of public policy are usually due to the complexity of policy, lack of consensus on the objectives of public policy, the existence of problems in starting new policies and the tendency to avoid policy accountability.

Human resource factors, as well as limitations in providing information, are obstacles that still need to continue to receive attention and improvement. This limitation is a separate work for the village apparatus how to provide understanding, support, and motivation to the community in order to understand and accept all forms of policy or any form of regulation that must be carried out for the sake of sustainability and usefulness of village development.

\section{Conclusion}

Community participation in each stage of development is still not optimal, especially in the implementation stage of village development. The lack of an active community in each stage of the development is due to the lack of understanding of the village community, the importance of their participation in supporting the development program.
Meanwhile, the steps in implementing the development program are the essential stages related to the success or failure of development programs in the villages that have been planned. The role of the Village Head to increase community participation is to involve the community in village development planning meetings and provide direction, motivation and a description of the benefits of community participation in building the village.

The Village Head has given his participation by carrying out duties by his duties and carrying out village government work plans based on community needs and fulfilment of infrastructure in the village. The ability of the Village Head in embracing and fostering his community is due to the situation in the village's social culture is still close. Factors in increasing community participation, namely in communication, resources and facilities and infrastructures in village development have been going well and strived to be by the socio-cultural conditions and budgetary capabilities that exist in Simojayan village.

In carrying out activities, there are several driving and inhibiting factors, both internally and externally. There is a conflict between policymakers and implementing policies. There is a problem catching information. This is related to the limitations of human resources and competencies in carrying out activities. Unclear information can be caused by perceptions and inability to understand a policy.

\section{ACKNOWLEDGEMENTS}

The most profound gratitude the author conveyed to the Rector of Merdeka Malang University

\section{REFERENCES}

1. Soenarko. Public policy: pengertian pokok untuk memahami dan analisa kebijaksanaan pemerintah. Surabaya: Airlangga University Press; 2005.

2. Pasolong H. Teori administrasi publik. Bandung: Alfabeta; 2007.

3. Widodo. Analisis kebijakan publik: konsep dan aplikasi analisis proses kebijakan publik. Malang: Bayu Media; 2011.

4. Sadhana K. Realitas kebijakan publik. Malang: Universitas Negeri Malang Press; 2011.

5. Abdul Wahab S. Analisis kebijaksanaan: dari formulasi ke implementasi kebijaksanaan negara. Jakarta: Pustaka Sinar Grafika; 2002.

6. Pace RW, Faules DF. Komunikasi organisasi. Bandung: Remaja Rosdakarya; 2006

7. Cohen J, Uphoff N. Rural development participation: concept and measures for project design. implementation and evaluation [Internet] 1980. Available from: https://www.researchgate.net/publication/37882394_Rural_Developme nt_Participation_Concept_and_Measures_for_Project_Design_Implem entation_and_Evaluation

8. Tarigan R. Perencanaan pembangunan wilayah. Jakarta: Bumi Aksara; 2009

9. Sugiyono. Metode penelitian uantitatif, kualitatif dan R\&D. Bandung: Alfabeta; 2011.

10. Miles MB, Huberman AM. Analisis data kualitatif. Jakarta: Universitas Indonesia Press; 1992.

11. Winarno B. Teori dan proses kebijakan publik. Yogyakarta: Media Pressindo; 2005 